\title{
Pengaruh Penyimpanan Dingin Terhadap Sosis Daging Sapi yang Ditambahkan Ekstrak Kulit Buah Naga Merah
}

\author{
Fitri M. Manihuruk \\ Balai Besar Pelatihan Peternakan Kupang, Jln. Timor Raya Km. 17 Noelbaki, Kupang Tengah, Kupang \\ e-mail : fitry0391@gmail.com
}

\begin{abstract}
This study aimed to evaluate the effect of cold storage on beef sausage added by red dragon fruit peel extract. Red dragon fruit peel extracts with $40 \%$ were added on dough of beef sausage. Sausage was stored at cold temperature $\left( \pm 4{ }^{\circ} \mathrm{C}\right)$ for 20 days. The cold storage treatment in this study was analysed on 0,5 th, 10th, 15th, and 20th days. The data were analyzed using analysis of variance and Duncan's multiple range test. The results showed that cold storage for 20 days had significantly difference on $\mathrm{pH}$ and $\mathrm{a}_{\mathrm{w}}$ value beef sausage added by red dragon fruit peel extract. $\mathrm{pH}$ value decreased until 20th days in storage. $a_{w}$ value decreased until 15th days and levelled off on 20th. Emulsion stability of beef sausage was not different and the result was $100 \%$. The cold storage treatment could effectively maintained total plate count until the day-20 on beef sausage added by red dragon fruit peel extract.
\end{abstract}

Keywords: beef sausage, cold storage, red dragon fruit peel extract

\begin{abstract}
Abstrak
Penelitian ini bertujuan mengevaluasi pengaruh penyimpanan dingin pada sosis daging sapi yang ditambahkan ekstrak kulit buah naga merah. Ekstrak kulit buah naga merah yang ditambahkan sebanyak $40 \%$ pada adonan sosis. Sosis disimpan pada suhu dingin $\left( \pm 4{ }^{\circ} \mathrm{C}\right)$ selama 20 hari. Perlakuan penyimpanan dingin pada penelitian ini dianalisis pada hari ke-0, 5 10, 15 dan 20. Data diolah dengan analisis ragam (ANOVA) dan dilanjutkan uji perbandingan berganda menggunakan uji Duncan. Hasil analisis menunjukkan bahwa penyimpanan dingin selama 20 hari berpengaruh nyata pada nilai $\mathrm{pH}$ dan $\mathrm{a}_{w}$ sosis daging sapi yang ditambahkan ekstrak kulit buah naga merah. Nilai pH menurun sampai hari ke-20. Nilai $a_{w}$ menurun sampai hari ke-15 dan stabil di hari ke-20. Stabilitas emulsi sosis daging sapi selama 20 hari penyimpanan dingin tidak berpengaruh nyata dan hasilnya adalah $100 \%$. Perlakuan penyimpanan dingin efektif mempertahankan angka lempeng total sampai hari ke20 pada sosis daging sapi dengan penambahan ekstrak kulit buah naga merah.
\end{abstract}

Kata Kunci: ekstrak kulit buah naga merah, penyimpanan dingin, sosis sapi

\section{PENDAHULUAN}

Daging sapi merupakan produk pangan yang mudah mengalami kerusakan karena mengandung nilai gizi yang tinggi sebagai sumber pertumbuhan mikroba. Untuk menghindari kerusakan, ada berbagai cara pengawetan yang dapat dilakukan sehingga memperpanjang masa simpannya. Salah satu cara pengawetan daging yang dilakukan adalah dengan pengolahan dan penyimpanan. Contoh pengolahan daging yang banyak ditemui adalah pembuatan sosis.

Sebelumnya telah dilakukan beberapa penelitian penambahan bahan aktif alami pada pembuatan sosis, salah satunya penambahan ekstrak kulit buah naga merah. Penambahan ekstrak kulit buah naga merah pada sosis sapi diteliti oleh Manihuruk et al. (2017) pada persentasi 0, 20, 30, dan 40\%. Berdasarkan hasil penelitian tersebut, penambahan ekstrak $40 \%$ merupakan 
persentase terbaik pada formula sosis sapi. Sosis yang dihasilkan memiliki karakteristik fisik lebih baik, aktivitas antioksidan lebih tinggi, dan keberadaan mikroba yang lebih rendah (Manihuruk et al. 2017).

Selain pengolahan, produk sosis memerlukan penyimpanan suhu dingin untuk mempertahankan kualitasnya, khususnya meminimalkan pertumbuhan mikroba. Menurut Penner (1990), sosis dapat bertahan selama 14-21 hari apabila disimpan pada suhu dingin $35-40 \mathrm{~F}\left(0-4^{\circ} \mathrm{C}\right)$. Sun et al. (2004) menyatakan bahwa keuntungan penyimpanan dingin produk olahan daging adalah menghambat penyebab pembusukan produk, seperti reaksi enzimatik lebih lambat dan menghambat pertumbuhan mikroorganisme.

Penyimpanan dingin ini diharapkan dapat mempertahankan karakteristik sosis sapi yang ditambahankan ekstrak kulit buah naga merah. Penelitian ini bertujuan mengevaluasi pengaruh penyimpanan dingin pada karakteristik fisik dan mikrobiologi sosis daging sapi yang ditambahkan ekstrak kulit buah naga merah.

\section{METODE}

Pembuatan ekstrak kulit buah naga merah dilakukan dengan maserasi modikasi Lourith dan Kanlayavattanakul (2013) menggunakan pelarut aquades $\mathrm{pH} 5$. Ekstrak yg dihasilkan disimpan pada suhu $20{ }^{\circ} \mathrm{C}$. Pengolahan sosis dilakukan sesuai dengan penelitian oleh Arief et al. (2014). Ekstrak kulit buah naga merah ditambahkan $40 \%$ dalam adonan. Sosis yang diperoleh disimpan pada suhu dingin $\left(0-4{ }^{\circ} \mathrm{C}\right)$ selama
20 hari. Pengamatan dilakukan pada hari ke0, 5 10, 15 dan 20.

\subsection{Analisis Fisik}

Nilai $\mathrm{pH}$ diukur dengan $\mathrm{pH}$ meter (Hanna HI 99163, HANNA Instruments, USA), dikalibrasi pada larutan buffer standar $\mathrm{pH} 4$ dan 7. Nilai $\mathrm{pH}$ diukur dengan memasukkan probe $\mathrm{pH}$ meter ke dalam sosis. Nilai $\mathrm{pH}$ akan terbaca pada layar $\mathrm{pH}$ meter. Nilai aw (water activity) diukur dengan $a_{w}$ meter (Novasiana, Switzerland). Sampel dihaluskan terlebih dahulu sebelum dilakukan pengujian. Prosedur pengukuran nilai $a_{w}$ dilakukan sesuai dengan petunjuk produsen.

Stabilitas emulsi diukur berdasarkan volume minyak dan air yang terukur berdasarkan Zobra et al. (1993). Stabilitas emulsi juga diukur pada sosis yang disimpan selama penyimpanan dingin. Sampel dipanaskan dalam waterbath suhu $80^{\circ} \mathrm{C}$ selama 30 menit. Selanjutnya sampel disentrifugasi dengan kecepatan 2000 rpm selama 15 menit. Volume minyak dan air diukur untuk menentukan stabilitas emulsi (ES) sampel, dengan rumus sebagai berikut.

$\mathrm{ES}_{1}(\%)=$ volume air $(\mathrm{mL}) \times 10$

$\mathrm{ES}_{2}(\%)=$ volume minyak $(\mathrm{mL}) \times \mathrm{d} \times 10$

$\mathrm{ES}(\%)=100-\left(\mathrm{ES}_{1}+\mathrm{ES}_{2}\right)$

Keterangan:

d : densitas lemak $\left(\mathrm{g} \mathrm{mL}^{-1}\right)$

ES : stabilitas emulsi

\subsection{Analisis Mikrobiologi}

Analisis mikrobiologis sampel dilakukan berdasarkan FDA (1998) dengan menghitung angka total lempeng yang menunjukkan nilai total mikroba pada suatu produk. Sosis ditimbang sebanyak $25 \mathrm{~g}$ dan dimasukkan ke dalam $225 \mathrm{~mL}$ buffer pepton water (BPW) dan dihomogenkan selama 1 
sampai 2 menit. Sehingga memperoleh pengenceran 101. Suspensi $1 \mathrm{~mL}$ dipindahkan dengan menggunakan pipet steril ke dalam larutan $9 \mathrm{~mL}$ BPW untuk mendapatkan pengenceran 10-2. Pengenceran dilanjutkan sampai pengenceran $10^{-4}$ dengan cara yang sama. Suspensi $1 \mathrm{~mL}$ dari pengenceran 10-2 sampai $10^{-4}$ dimasukkan dalam cawan petri secara duplo. Media plate count agar (Difco $^{\mathrm{TM}}$, USA) dituang sebanyak 15-20 mL ke dalam cawan dengan suhu $45^{\circ} \mathrm{C} \pm 1^{\circ} \mathrm{C}$. Cawan didiamkan sampai agar menjadi padat dan diinkubasi pada suhu $34-36{ }^{\circ} \mathrm{C}$ selama 24-48 jam dengan posisi terbalik.

\subsection{Analisis Data}

Data diolah dengan analisis ragam (ANOVA) menggunakan software Statistical Analysis System's Procedures (SAS Institute Inc., Cary, NC, USA, 2002). Jika analisis menunjukkan perlakuan berpengaruh nyata terhadap peubah yang diamati, maka dilanjutkan uji perbandingan berganda menggunakan uji Duncan. Perlakuan pada penelitian ini adalah perbedaan lama penyimpanan dingin.

\section{HASIL DAN PEMBAHASAN}

Sosis daging sapi dengan penambahan ekstrak kulit buah naga merah sebesar $40 \%$ berdasarkan penelitian Manihuruk et al. (2017) memiliki karakteristik fisik lebih baik, aktivitas antioksidan lebih tinggi, dan keberadaan mikroba lebih rendah dibanding penambahan ekstrak $20 \%$ dan $30 \%$. Sosis daging sapi dengan penambahan ekstrak $40 \%$ dianalisis karakteristiknya selama penyimpanan di suhu dingin $\left( \pm 4^{\circ} \mathrm{C}\right)$ pada hari ke-0, 5, 10, 15, dan 20. Analisis yang dilakukan meliputi nilai $\mathrm{pH}, \mathrm{a}_{\mathrm{w}}$, stabilitas emulsi dan angka lempeng total. Selama penyimpanan, nilai $\mathrm{pH}$ dan $\mathrm{a}_{\mathrm{w}}$ sosis akan berpengaruh pada bau dan cita rasa. Stabilitas emulsi sosis selama penyimpanan akan berpengaruh pada tekstur. Angka total lempeng sosis akan berpengaruh pada jumlah mikroba dan lama penyimpanan sosis. Hasil analisis terhadap karakteristik sosis daging sapi tersebut terdapat pada Tabel 1.

Tabel 1. Hasil analisis sosis daging sapi dengan persentase penambahan ekstrak kulit buah naga merah selama penyimpanan dingin

\begin{tabular}{lccccc}
\hline \multirow{2}{*}{ Parameter } & \multicolumn{5}{c}{ Penyimpanan hari ke- } \\
\cline { 2 - 6 } & 0 & 5 & 10 & 15 & 20 \\
\hline $\mathrm{pH}$ & $5.86 \pm 0.04 \mathrm{a}$ & $5.82 \pm 0.02 \mathrm{ab}$ & $5.82 \pm 0.02 \mathrm{ab}$ & $5.81 \pm 0.02 \mathrm{~b}$ & $5.67 \pm 0.03 \mathrm{c}$ \\
$\mathrm{a}_{\mathrm{w}}$ & $0.89 \pm 0.00 \mathrm{a}$ & $0.85 \pm 0.01 \mathrm{~b}$ & $0.84 \pm 0.00 \mathrm{c}$ & $0.82 \pm 0.00 \mathrm{~d}$ & $0.82 \pm 0.00 \mathrm{~d}$ \\
$\begin{array}{l}\text { Stabilitas emulsi } \\
(\%)\end{array}$ & $100.00 \pm 0.00$ & $100.00 \pm 0.00$ & $100.00 \pm 0.00$ & $100.00 \pm 0.00$ & $100.00 \pm 0.00$ \\
\hline $\begin{array}{l}\text { Angka lempeng } \\
\text { total (log cfu g }\end{array}$ & $2.91 \pm 0.35 \mathrm{c}$ ) & $3.24 \pm 0.03 \mathrm{bc}$ & $3.59 \pm 0.50 \mathrm{~b}$ & $5.05 \pm 0.09 \mathrm{a}$ & $5.25 \pm 0.09 \mathrm{a}$ \\
\hline Keterangan: Huruf yang berbeda pada baris yang sama menunjukkan berbeda sangat nyata $(\mathrm{p}<0.01)$
\end{tabular}

Hasil analisis sosis daging sapi yang tedapat pada Tabel 1 menunjukkan bahwa nilai $\mathrm{pH}$ dan $\mathrm{a}_{w}$ sangat nyata dipengaruhi oleh penyimpanan dingin $(\mathrm{p}<0.01)$. Pengaruh perlakuan penyimpanan suhu dingin selama 20 hari menurunkan nilai $\mathrm{pH}$ dan $\mathrm{a}_{\mathrm{w}}$ sosis daging sapi. Penurunan nilai $\mathrm{pH}$ sosis selama 
penyimpanan dingin disebabkan karena pertumbuhan mikroorganisme semakin meningkat selama penyimpanan. Abdalhai et al. (2014) menyatakan bahwa pertumbuhan mikroorganisme akan mempengaruhi karakteristik fisikokimia produk, seperti $\mathrm{pH}$ dan aw. Penurunan nilai $\mathrm{pH}$ sosis yang disimpan pada suhu dingin juga dihasilkan pada penelitian yang dilakukan oleh Jin et al. (2015) dan El-Nashi et al. (2015). Hal ini dikaitkan dengan adanya pemecahan glikogen hingga membentuk asam laktat pada sosis.

Penurunan nilai $a_{w}$ sosis daging sapi terjadi sampai pada penyimpanan hari ke-15 dan nilai stabil pada hari ke-20. Penurunan nilai $a_{w}$ juga terjadi pada penelitian sosis selama penyimpanan dingin oleh Bowser et al. (2014) dan Andrés et al. (2006). Kenaikan dan penurunan nilai $\mathrm{a}_{w}$ selama penyimpanan dingin disebabkan karena kelembaban lingkungan yang diperoleh (Utami et al. 2017). Apabila disimpan pada ruangan yang lebih kering maka produk akan menguapkan sebagian airnya, begitu juga sebaliknya. Penurunan atau kenaikan $\mathrm{pH}$ dan aw menurunkan kualitas sosis dan waktu penyimpanan produk akan semakin singkat.

Karakteristik fisik lainnya pada sosis daging sapi adalah stabilitas emulsi yang baik $(100 \%)$ selama 20 hari penyimpanan dingin. Stabilitas emulsi dipengaruhi oleh bahan pengikat yang ditambahkan pada pembuatan sosis. Stabilitas emulsi yang baik selama penyimpanan dingin ini disebabkan adanya penambahan STPP pada adonan sosis daging sapi yang mampu meningkatkan kemampuan protein untuk mengikat lemak dan air (Andrés et al. 2006).

Angka lempeng total sosis daging sapi sangat nyata dipengaruhi oleh perlakuan penyimpanan suhu dingin selama 20 hari $(p<0.01)$. Angka lempeng total sosis daging sapi pada penyimpanan hari ke-15 dan ke-20 pada hasil uji statistik tidak berbeda. Pengaruh perlakuan penyimpanan suhu dingin selama 20 hari meningkatkan angka lempang total sosis daging sapi. Namun, nilai angka lempeng total sosis daging sapi yang disimpan pada suhu dingin selama 20 hari masih memenuhi standar yang ditetapkan oleh BSN (1995) mengenai sosis daging yaitu maksimal $10^{5}$ koloni g $^{-1}$ atau $5 \log _{\text {cfu g }}{ }^{-1}$.

Angka lempeng total yang dapat dipertahan sosis daging sapi selama penyimpanan dingin dipengaruhi oleh senyawa antibakteri pada ekstrak kulit buah naga merah sehingga pertumbuhan bakteri dapat dihambat. Salah satu senyawa antibakteri tersebut adalah adalah tanin (Rohim et al. 2012). Berdasarkan uji kualitatif fitokimia pada penelitian Manihuruk et al. (2017), ekstrak kulit buah naga merah memiliki kandungan tanin dimana kandungan tersebut menunjukkan aktivitas antimikroba yang tinggi (Rohin et al. 2012).

Selain senyawa tanin, senyawa terpenoid dan saponin juga terdapat pada ekstrak kulit buah naga merah yang mampu menghambat aktivitas bakteri. Berdasarkan penelitian penelitian 
Manihuruk et al. (2017), ekstrak kulit buah naga merah memiliki kandungan terpenoid dan saponin. Senyawa terpenoid terdiri atas triterpenoid dan steroid yang memiliki aktivitas antibakteri yaitu bereaksi dengan protein dinding sel bakteri (Luo et al. 2014). Senyawa saponin mampu menembus sitoplasma bakteri sehingga pertumbuhan bakteri terhambat (Tenore et al. 2012).

Pengaruh perlakuan penyimpanan suhu dingin selama 20 hari meningkatkan angka lempang total sosis daging sapi. Peningkatan populasi bakteri selama penyimpanan dingin 60 hari juga dihasilkan pada penelitian Bostan dan Mahan (2011) dengan perlakuan penambahan bahan alami, kitosan. Bostan dan Mahan (2011) dan Andrés et al. (2006) menambahkan jenis bakteri yang umum ditemukan pada produk selama penyimpanan dingin adalah bakteri psikotropik, bakteri yang mampu tumbuh pada suhu dingin.

\section{KESIMPULAN DAN SARAN}

\subsection{Kesimpulan}

Penyimpanan dingin selama 20 hari berpengaruh pada nilai $\mathrm{pH}, \mathrm{a}_{\mathrm{w}}$, dan angka lempang total sosis daging sapi yang ditambahkan ekstrak kulit buah naga merah. Nilai $\mathrm{pH}$ menurun sampai penyimpanan hari ke-20. Nilai $a_{w}$ menurun sampai penyimpanan hari ke15 dan stabil di penyimpanan hari ke-20. Angka lempeng total masih memenuhi standar yaitu maksimal 5 log cfu $\mathrm{g}^{-1}$ sampai penyimpanan hari ke-20. Penyimpanan dingin selama 20 hari tidak mempengaruhi stabilitas emulsi sosis.

\subsection{Saran}

Pengaruh penyimpanan suhu ruang pada sosis daging sapi yang ditambahakan ekstrak kulit buah naga merah perlu dilakukan untuk mengetahui efektifitas penambahan ekstrak.

\section{UCAPAN TERIMA KASIH}

Terima kasih kepada Lembaga Pengelola Dana Pendidikan, Kementerian Keuangan, Republik Indonesia yang telah mendanai penelitian ini.

\section{DAFTAR PUSTAKA}

Abdalhai, M. H., Bashari, M., Lagnika, C., He, Q., \& Sun, X. (2014). Effect of ultrasound treatment prior to vacuum and modified atmosphere packaging on microbial and physical characteristics of fresh beef. Journal of Food and Nutrition Research, 2(6), 312-320.

Andrés, S. C., García, M. E., Zaritzky, N. E., \& Califano, A. N. (2006). Storage stability of low-fat chicken sausages. Journal of Food Engineering, 72, 311-319.

Arief, I. I., Suryati, T., Afiyah, D., \& Wardhani, D. (2014). Physicochemical and organoleptic of beef sausages with teak leaf extract (Tectona grandis) addition as preservative and natural dye. International Food Research Journal, 21(5), 2033-2042.

Bostan, K., \& Mahan, F. I. (2011). Microbiological quality and shelf-life of sausage treated with chitosan. $J$ Fac. Vet. Med. Istanbul Univ., 37(2), 117-126.

Bowser, T. J., Mwavita, M., Al-Sakini, A., McGlynn, W., \& Maness, N. O. (2014). Quality and shelf life of fermented lamb meat sausage with rosemary extract. The Open Food Science Journal, 8, 22-31.

Badan Standar Nasional. (1995). Sosis Daging (SNI 01-3820-1995). Jakarta, Indonesia: Badan Standar Nasional.

El-Nashi, H. B., Fattah, A. F. A. K. A., 
Rahman, N. R. A., \& El-Razik, A. (2015). Quality characteristics of beef sausage containing pomegranate peels during refrigerated storage. Annals Agricultural Science, 60(2), 403412.

Food and Drug Administration. (1998). Bacteriological Analytical Manual. ( $8^{\text {th }}$ ed). Arlington, USA: Food and Druf Administration.

Jin, S., Ha, S., \& Choi, J. (2015). Effect of Caesalpinia sappan L. extract on physico-chemical properties of emulsion-type pork sausage during cold storage. Meat Science, 110, 245-252.

Lourith, N., \& Kanlayavattanakul, M. (2013). Antioxidant and stability of dragon fruit peel colour. Agro Food Industry Hi-Tech, 24(3), 56-58.

Luo, H., Cai, Y., Peng, Z., Liu, T., \& Yang, S. (2014). Chemical composition and in vitro evaluation of the cytotoxic and antioxidant activities of supercritical carbon dioxide extracts of pitaya (dragon fruit) peel. Chemistry Central Journal, 8, 1-7.

Manihuruk, F. M., Suryati, T., \& Arief, I. I. (2017). Effectiveness of the red dragon fruit (Hylocereus polyrhizus) peel extract as the colorant, antioxidant, and antimicrobial on beef sausage. Media Peternakan, 40(1), 47-54.

Penner, K. P. (1990). Refrigerator/freezer approximate storage times.
Manhattan, USA: Kansas State University.

Rohin, M. A. K., Bakar, A., Abdullah, C., \& Ali, A. M. (2012). Antibacterial activity of flesh and peel methanol fractions of red pitaya, white pitaya and papaya on selected food microorganisms. International Journal of Pharmacy and Pharmaceutical Sciences, 4(3), 185-190.

Sun, S., Singh, R. P., \& O' Mahony, M. (2004). Quality of meat products during refrigerated and ultra-chilled storage. Journal of Food Quality, 28, 30-45.

Utami, R., Agustini, T. W., \& Amalia, U. (2017). Aplikasi edible coating semi refined karaginan terhadap daya simpan sosis ikan kurisi (Nemipterus nematophorus) pada penyimpanan suhu dingin. J. Peng. \& Biotek. Hasil Pi., 6(2), 24-32.

Tenore, G. C., Novellino, E., \& Basile, A. (2012). Nutraceutical potential and antioxidant benefits of red pitaya (Hylocereus polyrhizus) extracts. Journal of Functional Food, 4, 129136.

Zobra, O., Gokalp, H. Y., Yetim, H., \& Ockerman, H. W. (1993). Model system evaluations of the effects of different levels of $\mathrm{K}_{2} \mathrm{HPO}_{4}, \mathrm{NaCl}$ and oil temperature on emulsion stability and viscosity of fresh and frozen Turkish style meat emulsion. Meat Science, 34, 145-161. 